\title{
ANALYSIS OF THE VARIABLES THAT AFFECT FREQUENCY OF USE AND TIME SPENT ON TEXT MESSAGING
}

\author{
Alan Peslak, Penn State University, arp14@psu.edu \\ Wendy Ceccucci, Quinnipiac University, wendy.ceccucci@quinnipiac.edu \\ Neelima Bhatnagar, University of Pittsburgh at Johnstown, bhatnagr@pitt.edu
}

\begin{abstract}
This manuscript provides a comprehensive review of the many potential variables associated with the use of technology and tests their applicability to text messaging. Variables were included from a variety of well accepted theories including Theory of Reasoned Action, Diffusion of Innovation, Theory of Planned Behavior, Technology Acceptance Model and End User Computer Satisfaction. Prior studies have explored variables and factors that influence text messaging intention and behavior. This study is an extension of a prior study that reviewed factors associated with text messaging behavior and intention. This study is unique in that it does not review the intention or usage of the technology but rather explores the frequency of use and the amount of time spent using the technology. As a result, we can explore the relative importance of the technology and its time and frequency penetration on the part of users rather than just a generic variable measuring agreement with an intention to use and actual use.
\end{abstract}

Keywords: Text Messaging, SMS, Texting, Theory of Reasoned Action, Diffusion of Innovation, Technology Acceptance Model

\section{INTRODUCTION}

Short message service (SMS) or what is more commonly referred to as text messaging or simply texting allows users to send short messages quickly and privately to a specific individual. Text messaging has become a widely accepted method of communication. According to a study done by Pew Internet [27], 83\% of American adults own cell phones and three-quarters of them $(73 \%)$ send and receive text messages. The study also found that when asked how they prefer to be contacted on their cell phone 31\% said they preferred texts to talking on the phone, while 53\% said they preferred a voice call to a text message. Another $14 \%$ said the contact method they prefer depends on the situation.

In an attempt to understand text messaging behavioral factors associated with the use of technology, this paper explores text messaging behavior using variables from five models on human behavior: End User Computer Satisfaction (EUCS); Theory of Reasoned Action (TRA); Theory of Planned Behavior (TPB); Technology Acceptance Model (TAM) and Diffusion of Innovation (DI). The authors explored variables from each of these models for their effect on text messaging usage. In addition, the authors included several common emotions in the statistical analysis.

\section{LITERATURE REVIEW}

\section{Text messaging}

Text messaging has been around for 20 years. (The proliferation of cellular phones (aka mobile phones) makes it possible for over four billion people or two-thirds of the world's population to text message [17]. According to Holmes [13], in 2010, “...4.16 billion users made SMS the most popular data channel in the world." The MBAOnline website [22] posted some interesting statistics when it comes to the proliferations of text messaging. More specifically:

- There are 4.2 billion users of text messaging

- 6.2 trillion texts were sent around the world in 2010 


\section{Issues in Information Systems}

Volume 13, Issue 1, pp. 361-370, 2012

- The feature phone (aka dumb phone) is the number one electronic device sold in the world

- In the developing world: two out of three people have mobile phone subscriptions, 48 million people around the world have cell phones but no electricity, 1.7 billion users have phones but no bank accounts

While the use of text messaging continues to grow in developing nations, a reversal in trend is occurring in other parts of the world, including the United States [34]. According to UBS analyst John Hodulik, the United States has experienced a slowdown in growth over the last several years. This slowed growth can be attributed to the cost associated of sending text messages and the proliferation of alternative communication methods including Facebook, Twitter, Blackberry Messenger, and iMessage [7, 33].

According to the Pew Internet \& American Life Project [27] text messaging users "send or receive an average of 41.5 messages on a typical day, with the median user sending or receiving 10 texts daily. The 18-24 age group is the largest user of text messaging sending or receiving an average of 109.5 messages daily. Below are some interesting statistics taken from NetBlueWeb [18] on the use and response time of text messaging.

- Voice calling is decreasing as text messaging increases amongst American adults

- Over 8 trillion text messages were sent in 2011 which makes this service surpass traditional telephone conversations.

- $90 \%$ of all text messages are read within 3 minutes of their delivery

- $\quad 97 \%$ of text messages are opened, while only $22 \%$ of emails are opened

- The average response time it takes to respond a text message is 90 seconds

- $45 \%$ of 21-50 year olds polled prefer texting to voice calling

- $50 \%$ of all text message users in the United States are over the age of 35.

\section{Variables and Mathematical Models}

This work is an extension of a prior study [6] that reviewed the variables from the five noted models of human behavior and explored their effect on intention to use text messaging and actual text messaging behavior. Specifically the variables that were reviewed included: compatibility, complexity, relative advantage and visibility from DI; attitude from TRA; perceived behavioral control from TPB; ease of use and usefulness from TAM; and timeliness from EUCS. A brief overview of each of these models is given below.

\section{Rogers' Diffusion of Innovation Theory}

According to Rogers [24] diffusion is "a process by which an innovation is communicated through certain channels over time among the members of a social system." Diffusion of Innovation theory attempts to explain how, why, and at what rate new ideas and technology are communicated and adopted.

Rogers [24] identified five factors five major factors affecting the rate of adoption. These factors are:

- relative advantage - the degree to which the adopter perceives the innovation to represent an improvement in the innovation it supersedes.

- complexity - the degree to which the innovation is difficult to understand or apply.

- compatibility- the degree to which an innovation is perceived as being consistent with the existing values, past experiences, and needs of potential adopters.

- trialability refers to the capacity to experiment with the new technology before adoption.

- observability or visibility refers to the degree to which the results of the innovations are visible to others.

According to Rogers [24] critical mass occurs when enough individuals have adopted the innovation and its further rate of adoption becomes self-sustaining. 


\section{Issues in Information Systems}

Volume 13, Issue 1, pp. 361-370, 2012

\section{Theory of Reasoned Action}

Theory of Reasoned Action (TRA), developed by Ajzen and Fishbein [3] has continued to be an important model for measuring user behavior [5, 19, 32, 34]. The model is shown in Figure 1. TRA suggests that a person's behavioral intention depends on the person's attitude about the behavior and subjective norms. Intention to use is a common behavioral factor $[4,16]$. Actual behavior generally follows intention in a variety of models $[4,33]$. Definitions of the models factors are as follow:

- Attitude - how we feel about the behavior and is generally measured as a favorable or unfavorable mind-set.

- Subjective norm - is how the behavior is viewed by our social circle or those who influence our decisions.

- Intention -is the propensity or intention to engage in the behavior.

- Behavior - is the actual behavior itself.

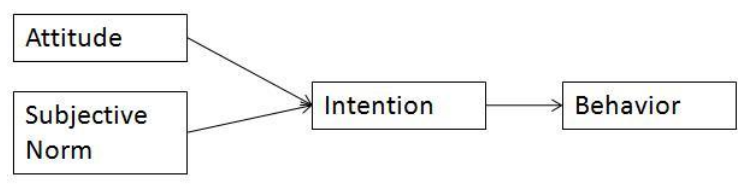

Figure 1: Theory of Reasoned Action Model

\section{Theory of Planned Behavior}

Ajzen's Theory of Planned Behavior (TPB) is an extension of Ajzen and Fishbein's TRA Model [2, 3]. TPB includes an additional factor, perceived behavioral control which is a person's "perceptions of their ability to perform a given behavior" [2]. In other words, the person's perceived ease or difficulty of performing the behavior. The greater a person's perceived behavioral control, the stronger should be their intention to perform the behavior. For example, "if I consider that I have the necessary resources (e.g. time, means of transport) to attend a meeting with a class teacher then I am more likely to form an intention to perform the behavior... of meeting with the class teacher" [31].

\section{Technology Acceptance Model}

One of the most important models for understanding adoption of information technology is the Technology Acceptance Model (TAM). The model was first proposed by Davis [8] in 1989 and includes two key factors, perceived usefulness and perceived ease of use that are proposed to influence acceptance of a technology. According to Davis [8] perceived usefulness is defined as "the degree to which a person believes that using a particular system would enhance his or her job performance". Others have extended this definition to include overall task performance [26]. Again, according to Davis [8] perceived ease of use is "the degree to which a person believes that using a particular system would be free of effort". The Technology Acceptance Model is illustrated in Figure 2. [30].

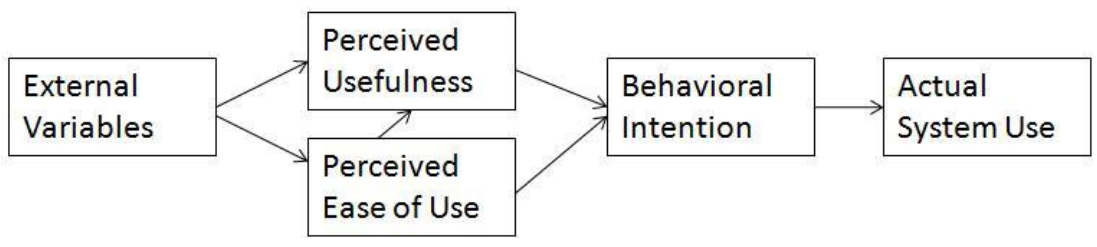

Figure 2: Technology Acceptance Model 


\section{Issues in Information Systems}

Volume 13, Issue 1, pp. 361-370, 2012

\section{End User Computing Satisfaction}

Ease of use and timeliness factors used to evaluate the effect of text messaging behavior were taken from the dimensions used in the End User Computing Satisfaction Instrument, shown in Figure 3. The EUCS instrument was developed by Doll and Torkzadeh [9] and is an extension of the User Information Satisfaction Model (UIS) that was previously developed by Ives, Olson and Baroudi [15]. The EUCS instrument defines five factors that influence user satisfaction: content, accuracy, format, ease of use, and timeliness. Timeliness measured whether the information was supplied in time and if it was up to date.

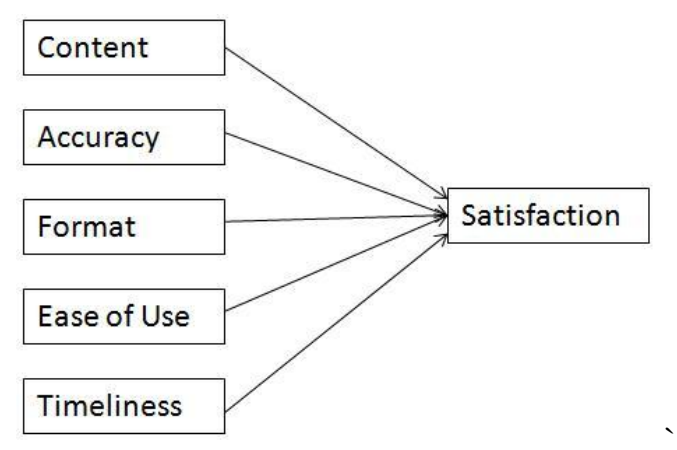

Figure 3: End User Computing Satisfaction Instrument

\section{Emotions}

Many researchers have found that emotions can play a role in performance. Peslak and Stanton [20] found emotions to have an impact on team performance. Other researchers, Glinow et al.,[12] and Sy et al. [29] have shown that emotions can play a significant role in project success. To study the impact of emotions on text messaging, a small group of 4 positive emotions was included in the survey. The list was extracted from Shaw [25] and others.

\section{RESEARCH APPROACH}

A comprehensive survey was developed to explore all aspects of text messaging usage. The survey included key questions used in the development of past studies of Theory of Reasoned Action, Technology Acceptance Model, Theory of Planned Behavior, End User Computer Satisfaction, Expectation/Confirmation Theory, and Diffusion of Innovation. Table 1shows the variables, model, and source for questions that were used in this study. One key question was selected for each variable. The study was pre-tested with a small group of students and then administered to students and faculty at two Northeastern universities as well as a limited group of professionals in industry. 


\section{Issues in Information Systems}

Volume 13, Issue 1, pp. 361-370, 2012

Table 1: Factor Models and References

\begin{tabular}{|l|l|l|l|}
\hline Variable & Actual survey question & Model & $\begin{array}{l}\text { Questions adapted } \\
\text { from }\end{array}$ \\
\hline Attitude & Text messaging is good. & $\begin{array}{l}\text { Theory of Reasoned } \\
\text { Action/TPB }\end{array}$ & Fitzmaurice [10] \\
\hline Compatibility & $\begin{array}{l}\text { Text messaging is completely } \\
\text { compatible with my current } \\
\text { situation. }\end{array}$ & Diffusion of Innovation & $\begin{array}{l}\text { Ilie, Van Slyke, } \\
\text { Green, \& Lou [14] }\end{array}$ \\
\hline Complexity & Text messaging is frustrating & Diffusion of Innovation & $\begin{array}{l}\text { Ilie, Van Slyke, } \\
\text { Green, \& Lou [14] }\end{array}$ \\
\hline Critical Mass & $\begin{array}{l}\text { Many people use Text } \\
\text { messaging. }\end{array}$ & Diffusion of Innovation & $\begin{array}{l}\text { Ilie, Van Slyke, } \\
\text { Green, \& Lou [14] }\end{array}$ \\
\hline Ease of Use & Text messaging is easy to do. & $\begin{array}{l}\text { Technology Acceptance Model } \\
\text { /EUCS }\end{array}$ & Davis [8] \\
\hline Emotions & $\begin{array}{l}\text { Pleased Satisfied Contented } \\
\text { Delighted }\end{array}$ & Emotions & Peslak [20] \\
\hline $\begin{array}{l}\text { Perceived } \\
\text { Behavioral } \\
\text { Control }\end{array}$ & $\begin{array}{l}\text { Text messaging is entirely } \\
\text { within my control. }\end{array}$ & Theory of Planned Behavior & $\begin{array}{l}\text { Venkatesh \& } \\
\text { Morris [30] }\end{array}$ \\
\hline $\begin{array}{l}\text { Relative } \\
\text { advantage }\end{array}$ & $\begin{array}{l}\text { Text messaging improves my } \\
\text { productivity. }\end{array}$ & Diffusion of Innovation & George [11] \\
\hline $\begin{array}{l}\text { Timeliness } \\
\text { information quickly }\end{array}$ & $\begin{array}{l}\text { I find Text messaging useful } \\
\text { Usefulness }\end{array}$ & $\begin{array}{l}\text { Technology Acceptance } \\
\text { Model/ECT }\end{array}$ & $\begin{array}{l}\text { Abdinnour-Helm, } \\
\text { Chaparro, \& } \\
\text { Farmer [1] }\end{array}$ \\
\hline $\begin{array}{l}\text { Visibility } \\
\text { messaging. }\end{array}$ & Diffusion of Innovation & Davis [8] \\
\hline
\end{tabular}

The statistical analyses were based on a sample of 153 valid surveys. Since the surveys were collected in classes, response rate was near 100\%. Of the surveys collected $42 \%$ were from males and $58 \%$ were from females. Overall, the average age was about 33 years of age, but the largest group was the 18-24 year old students. There was a large portion of the sample (45\%) over 24. There were 89 female participants and 63 male participants. Gender mix was good with 58\% female and $42 \%$ male. Fifty-five percent of the respondents were students (age 18-24) and $45 \%$ were not.

Another demographic question examined the current professional status of the respondent, whether they were a student, a faculty member, and IT professional or from the private sector. 86(57\%) of the respondents were students, 11(7\%) faculty, 11(7\%) IT professionals, and 43(29\%) were from others. We propose the sample has a reasonable mix of gender, age, and professional status.

\section{RESULTS}

The variables noted above were analyzed using SPSS 17.0 using multiple regression analysis. As noted, past studies have reviewed these variables relative to behavioral intention and use. Our study explored this further by examining the frequency of usage and time spent with each technology. The goal of this study was to determine the relative importance of the technology through its time and frequency penetration on the part of users rather than just a generic variable measuring agreement with an intention to use and actual use. 


\section{Issues in Information Systems}

Volume 13, Issue 1, pp. 361-370, 2012

A prior study of the data[6] revealed that the factors that significantly correlated with intention to use text messaging were attitude, compatibility, ease of use, satisfaction, and visibility. But this study revealed much different results. Though these factors may be important in an overall intention to use, they do not map to frequency or time spent. In Table 2 we see that only compatibility is significantly and positively correlated with frequency of usage. As noted, compatibility comes from Diffusion of Innovation and reflects to the degree to which an innovation is perceived as being consistent with the existing values, past experiences, and needs of potential adopters. Frequency of use of text messaging is solely and directly related to addressing a communication need. It provides non-intrusive asynchronous communications for its users and it will be used most frequently the more this need is recognized and needed. This provides a direct variable which can be used to expand usage of text messaging across underutilized populations of users. Efforts can be directed to communicating how text messaging extends users' existing communications methods.

Table 2 Variables Affecting Text Messaging Frequency of Use

\begin{tabular}{|c|c|c|c|c|c|}
\hline \multirow[t]{2}{*}{ Model } & \multicolumn{2}{|c|}{$\begin{array}{c}\text { Unstandardized } \\
\text { Coefficients } \\
\end{array}$} & \multirow{2}{*}{$\begin{array}{c}\text { Standardized } \\
\text { Coefficients } \\
\text { Beta }\end{array}$} & \multirow[b]{2}{*}{$\mathrm{t}$} & \multirow[b]{2}{*}{ Sig. } \\
\hline & $\mathrm{B}$ & Std. Error & & & \\
\hline 1 (Constant) & 5.542 & .861 & & 6.438 & .000 \\
\hline Text messaging is good. & .179 & .171 & .166 & 1.049 & .297 \\
\hline Many people use Text messaging. & -.229 & .156 & -.225 & -1.468 & .145 \\
\hline Text messaging is frustrating. & -.033 & .114 & -.026 & -.287 & .775 \\
\hline $\begin{array}{l}\text { Text messaging is completely compatible with my } \\
\text { current situation. }\end{array}$ & .246 & .118 & .213 & 2.081 & .040 \\
\hline Text messaging is easy to do. & .188 & .169 & .156 & 1.109 & .270 \\
\hline Text messaging improves my productivity. & .080 & .128 & .063 & .622 & .536 \\
\hline Text messaging is entirely within my control. & -.162 & .143 & -.134 & -1.134 & .260 \\
\hline Pleased & .086 & .482 & .060 & .179 & .859 \\
\hline Satisfied & -.025 & .404 & -.017 & -.062 & .950 \\
\hline Contented & -.242 & .376 & -.168 & -.644 & .521 \\
\hline Delighted & -.280 & .227 & -.201 & -1.232 & .221 \\
\hline $\begin{array}{l}\text { Text messaging provides needed information } \\
\text { quickly. }\end{array}$ & .001 & .223 & .001 & .004 & .997 \\
\hline I find Text messaging useful. & .291 & .252 & .267 & 1.154 & .251 \\
\hline I have seen many people Text messaging. & -.203 & .187 & -.188 & -1.086 & .280 \\
\hline
\end{tabular}

Dependent Variable: how often text messaging used

Table 3 is a regression study that reviews time spent text messaging as its dependent variable. Here we see that there are no variables that are significant at $p<.05$ but there are three that have weaker support at $p<.10$. They are compatibility, critical mass and perceived behavioral control. A layman's definition of perceived behavioral control is "This refers to the perceived ease or difficulty of performing the behavior. The greater a person's perceived behavioral control, the stronger should be their intention to perform the behavior.

This new variable suggests, those who view the importance and advantages of the control that text messaging provides, will use the service for longer periods of time. Those who also perceive that they have the resources both physical and temporal as well as knowledge of use and advantages will use text messaging for more time. To improve and increase text messaging, physical devices need to be readily available and easily facilitate the texting 


\section{Issues in Information Systems}

Volume 13, Issue 1, pp. 361-370, 2012

process. Critical mass was also found to be significant in time spent messaging. Critical mass according to Ilie, Van Slyke, Green, \& Lou [14] is the concept that as more and more users adopt a technology the more it is advantageous to each individual user. With so many people text messaging, more and more time is spent by each individual user texting. This suggests that in order for a technology to have greater time usage, it needs to be perceived as a ubiquitous technology. This is something that can be influenced by practitioners through advertising and other communications efforts. Finally, the process needs to be an extension of past behavior and address needs of users through compatibility. Those who use the technology for the most time will have the proper resources and see the benefits of the asynchronous technology.

Table 3 Variables Affecting Time Spent Text Messaging

\begin{tabular}{|c|c|c|c|c|c|}
\hline \multirow[t]{2}{*}{ Model } & \multicolumn{2}{|c|}{ Unstandardized Coefficients } & \multirow{2}{*}{$\begin{array}{c}\text { Standardized } \\
\text { Coefficients } \\
\text { Beta }\end{array}$} & \multirow[b]{2}{*}{$\mathrm{t}$} & \multirow[b]{2}{*}{ Sig. } \\
\hline & $\mathrm{B}$ & Std. Error & & & \\
\hline 1 (Constant) & 2.352 & .723 & & 3.253 & .002 \\
\hline Text messaging is good. & .023 & .144 & .027 & .163 & .871 \\
\hline Many people use Text messaging. & -.232 & .131 & -.287 & -1.770 & .080 \\
\hline Text messaging is frustrating. & -.025 & .096 & -.025 & -.264 & 793 \\
\hline $\begin{array}{l}\text { Text messaging is completely compatible } \\
\text { with my current situation. }\end{array}$ & 171 & .099 & .187 & 1.725 & .088 \\
\hline Text messaging is easy to do. & 179 & 142 & 188 & 1.260 & 211 \\
\hline Text messaging improves my productivity. & .078 & .108 & .077 & .724 & 471 \\
\hline $\begin{array}{l}\text { Text messaging is entirely within my } \\
\text { control. }\end{array}$ & .214 & .120 & .224 & 1.783 & .078 \\
\hline Pleased & .385 & .405 & 341 & .950 & .344 \\
\hline Satisfied & .067 & .339 & .058 & .196 & .845 \\
\hline Contented & -.514 & .316 & -.449 & -1.627 & 107 \\
\hline Delighted & -.227 & 191 & -.206 & -1.191 & 237 \\
\hline $\begin{array}{l}\text { Text messaging provides needed } \\
\text { information quickly. }\end{array}$ & .172 & .187 & .189 & .922 & .359 \\
\hline I find Text messaging useful. & -.025 & 212 & -.028 & -.116 & .908 \\
\hline I have seen many people Text messaging. & -.119 & 157 & -.139 & -.755 & .452 \\
\hline
\end{tabular}

Dependent Variable: time

\section{LIMTITATIONS AND IMPLICATIONS}

As with any study there are limitations to this study. First, the study examines primarily traditional students and administrators at two undergraduate university locations. Though this is a convenience sample, the use of students and other related personnel is a common method in IT research. It can also be suggested that university students and related individuals represent a high penetration population allowing for rich exploration of influencing variables. Results however, ought to be replicated across other locations. Though this group does represent a population of significant users, results may be different with non-students or with other age groups. Another limitation is the sample size. Though sizable, the number of participants can be increased to improve reliability.

A major implication of the study is that certain variables which were shown to be significant in intention to use text messaging have been significantly reduced through exploration of actual quantitative usage variables. First, from a 


\section{Issues in Information Systems}

Volume 13, Issue 1, pp. 361-370, 2012

theoretical perspective this calls into question the exclusive use of behavioral intention as a definitive variable for technology acceptance and usage. When our study was first performed with the traditional variable of behavioral intention, five variables were found to correlate with the behavioral intention to use text messaging. The text messaging variable however says nothing about actual extent of usage. When our study examined frequency of use and time spent using, we found that only one variable affects frequency of use and three affected time spent messaging (including one not significant in intention). Though this is a limited study, we believe this finding calls into question the ubiquitous use of behavioral intention as the dependent variable for technology penetration. We intend to explore this issue in much more detail with a variety of other technologies as well as a variety of survey populations.

Another major implication is the one that we set out to determine via our study. We explored specific variables from a wide variety of technology adoption models to determine what actually influences extent of use of text messaging. As noted, we found compatibility, critical mass, and perceived behavioral control as variable influencing time spent and compatibility influencing frequency. This, as noted, suggests that efforts can be focused in these areas by practitioners to expand the usage of this important asynchronous communications technology.

A final implication is that critical mass, from modified Diffusion of Innovation theory, is important for time spent using a technology. We found that those who viewed that "Many people use text messaging" will have more time spent texting. This has possible broader implications for other technologies including social networking. Work will be undertaken to explore these areas.

\section{CONCLUSION}

Overall, this study has provided significant variables that influence and affect text messaging frequency of use and time spent using the technology. We see this as the continuation of an exploration of ways to increase and improve penetration of this valuable communications technology. Studies can be developed to confirm these findings with larger and more diverse sample groups, but preliminary findings suggest that text messaging frequency of use and time spent text messaging are subject to efforts to improve usage through attention to the significant influencing variables of compatibility, critical mass, and behavioral control.

\section{REFERENCES}

1. Abdinnour-Helm, S. F., Chaparro, B. S., and Farmer, S. M. (2005). Using the End-User Computing Satisfaction (EUCS) Instrument to Measure Satisfaction with a Web Site. Decision Sciences ,36(2), 341-365.

2. $\quad$ Ajzen, I. (1985)."From intentions to actions: A Theory of Planned Behavior," in (Eds.), J. Kuhl \& J. Beckmann Action control: From cognition to behavior, Berlin, Heidelber, New York: Springer-Verlag.

3. Ajzen, I. and Fishbein, M. (1980). Understanding Attitudes and Predicting Social Behavior. Englewood Cliffs: Prentice-Hall, Inc.

4. Bahmanziari, T., Pearson, M. J., and Crosby, L. (2003). Is Trust Important in Technology Adoption? A Policy Capturing Approach. The Journal of Computer Information Systems, 43(4), 46-54.

5. Brewer, J., Blake, A., Rankin, S., and Douglass, L. (1999). Theory of Reasoned Action Predicts Milk Consumption in Women. Journal of the American Dietetic Association, 99(1), 39-44.

6. Ceccucci, W., Peslak, A., and Sendall, P. (2010). An Empirical Study Of Behavioral Factors Influencing Text Messaging Intention, Journal of Information Technology Management, 21(1), 16-34.

7. Chen, B.X..(2012) Text messaging is in decline in some countries. Retrieved from http://bits.blogs.nytimes.com/2012/01/01/text-messaging-is-in-decline-in-some-countries/.

8. Davis, F. D. (1989). Percieved Usefulness, Perceived Ease of Use, and User Acceptance of Infomration Technology. MIS Quarterly, 13(3), 319-340.

9. Doll, W., and Torkzadeh, G. (1988). The measurement of end-user computing satisfaction. MIS Quarterly, 12(6), 259-274. 


\section{Issues in Information Systems}

Volume 13, Issue 1, pp. 361-370, 2012

10. Fitzmaurice, J. (2005). Incorporating Consumers' Motivations into the Theory of Reasoned Action. Psychology \& Marketing, 22( 11), 911-929.

11. George, J. (2004). The theory of planned behavior and Internet purchasing. Internet Research, 14(3), 198-212.

12. Glinow, M., Shapiro, D., and Brett, J. (2004). Can we talk, and should we? Managing emotional conflict in multicultural teams. Academy of Management Review, 29(4), 578-92.

13. Holmes, Jamie. (2011). Why texting is the most important information service in the world. Retrieved from http://www.theatlantic.com/technology/archive/2011/08/why-texting-is-the-most-importantinformation-service-in-the-world/242951/.

14. Ilie, V., Van Slyke, C., Green, G., and Lou, H. (2005). Gender Difference in Perception and Use of Communication Technologies: A Diffusion of Innovation Approach. Information Resources Management Journal. 18(3), 13-31.

15. Ives, B., Olson, M., and Baroudi, J. (1983). The measurement of of user information satisfaction," Communications of the ACM , 2(10), 785-793.

16. Lu, J., Yu, C.-S., and Liu, C. (2005). Facilitating Conditions, Wireless Trust and Adoption Intention. The Journal of Computer Information Systems, 46(1), 17-24.

17. Naughton, John. (2012). Now 4 billion people know the joy of txt." Retrieved from http://www.guardian.co.uk/technology/2012/may/06/sms-text-messages-20th-birthday?newsfeed=true.

18. NetBlueWeb. (2012). Text Messaging Marketing. Retrieved from http://netblueweb.com/services/textmessage-marketing.

19. Pak, H. S. (2000). Relationships Among Attitudes and Subjective Norms: Testing the Theory of Reasoned Action Across Cultures. Communication Studies, 51(2), 162-175.

20. Peslak, A., and Stanton, M. (2007). Information technology team achievement: an analysis of success factors analysis and development of a team success model (TSM). Team Performance Management, 13(1/2), 21-33.

21. Peslak, A. R. (2005). Emotions and team projects and processes. Team Performance Management, 11(7/8), 251-262.

22. Planet Text, (2011). "How SMS Messaging is changing the world". Retrieved from http://www.mbaonline.com/planet-text/.

23. Riemenschneider, C. K., and Hargrove, B. C. (2001). Explaining Software Development Tool Use With The Technology Acceptance Model. The Journal of Computer Information Systems, 41(4), 1-8.

24. Rogers, E. (1995). Diffusion of Innovations, 4th Edition. New York, NY: Free Press.

25. Shaw, T. (2004). The emotions of systems developers: an empirical study of affective events theory. Proceedings of SIGMIS'04, 124-126.

26. Simon, S.J., and Paper, D. (2007). User Acceptance of Voice Recognition Technology: An Empirical Extension of the Technology Acceptance Model. Journal of Organizational and End User Computing, 19(1), 24-50.

27. Smith, Aaron. (2011). Americans and text messaging. Pew Internet \& American Life Project. Retrieved from http://pewinternet.org/Reports/2011/Cell-Phone-Texting-2011/Summary-of-Findings.aspx.

28. Song, J., and Kim, Y. J. (2006). Social Influence Process in the Accptance of a Virtual Community Service. Information Systems Front, 8, 241-152.

29. Sy, T., Cote, S., and Saavedra, R. (2005). The contagious leader: impact of the leader's mood on the mood of group members, group affective tone, and group processes. Journal of Applied Psychology, 90(2), 295-305.

30. Venkatesh, V., and Morris, M.(2000). Why Don't Men Ever Stop to Ask for Directions? Gender, Social Influence, and Their Role in Technology Acceptance and Usage Behavior. MIS Quarterly, 24(1), 11539.

31. Williamson, G. (2009). Stir! Speech Therapy Information and ResourcesPerceived Behavioral Control. Retrieved from http://www.speech-therapy-information-and-resources.com/theory-of-plannedbehavior.html.

32. Wooley, D., and Eining, M. (2009). Software Piracy among Accounting Students: A Longitudinal Comparison of Chance and Sensitivity. Journal of Information Systems, 20( 1), 49-63. 


\section{Issues in Information Systems}

Volume 13, Issue 1, pp. 361-370, 2012

33. Wortham, Jenna. (2011). Free texts pose threat to carriers. Retrieved from http://www.nytimes.com/2011/10/10/technology/paying-to-text-is-becoming-passe-companiesfret.html?_r=2\&pagewanted=all.

34. Woyke, Elizabeth. (2011). Text messaging decline in U.S. threatens carrier profits. Retrieved from http://www.forbes.com/sites/elizabethwoyke/2011/06/03/analyst-text-messaging-declin-in-u-s-threatencarrier-profits.

35. Wu, J., and Liu, D. (2007). The Effects of Trust and Enjoyment on Intention to Play Online Games. Journal of Electronic Commerce Research , 8(2), 128-140. 